\section{Epidemiology of pterygium on a tropical island in the Riau Archipelago}

${ }^{1}$ The Eye Institute at Tan Tock Seng Hospital, National Healthcare Group,

Singapore

${ }^{2}$ Department of

Community, Occupational and Family Medicine, National University of Singapore, Singapore

${ }^{3}$ Singapore National Eye Centre, Singapore

${ }^{4}$ Department of

Gastroenterology, Tan Tock Seng Hospital, Singapore

${ }^{5}$ The Eye Institute at Alexandra Hospital, National Healthcare Group,

Singapore

${ }^{6}$ Department of Ophthalmology, National University of Singapore, Singapore

${ }^{7}$ Singapore Eye Research Institute, Singapore

Correspondence: CSH Tan, The Eye Institute, National Healthcare Group, Tan Tock Seng Hospital, 11 Jalan Tan Tock Seng, Singapore 308433, Singapore Tel: + 65 63577726; Fax: + 6563577718 . E-mail: Colintan_eye@ yahoo.com.sg

Received: 18 March 2005 Accepted: 6 July 2005 Published online: 16 September 2005
Abstract

Objectives To describe the epidemiology of pterygium among residents of an island in Indonesia and to examine the roles of age and gender as determinants of bilaterality and severity of the disease.

Methods Voluntary eye screening on Pulau Jaloh, Riau Archipelago, Indonesia. Gender difference was tested using the $\chi^{2}$ test. The difference in age between subjects with and without disease was tested using unpaired Student's $t$-test. Odds ratio (relative risk) for gender was calculated using logistic regression model with adjustment for age.

Results Of the 550 inhabitants, $477(86.7 \%)$ responded to the eye screening. The overall prevalence rate of pterygium was $17.0 \%$. Out of 211,48 male $(22.7 \%)$ and 33 out of 266 female subjects $(\mathbf{1 2 . 4 \%})$ had the disorder, with the gender difference being statistically significant. Adjusted for age, the risk of disease was 3.1-fold higher among the males. In all, $71.6 \%$ of subjects with pterygium had bilateral disease. Subjects with pterygium were significantly older, their mean age being 42.9 years compared to $\mathbf{1 8 . 7}$ years among those without disease. The prevalence rates in male subjects increased from age 20 to reach a plateau of $63.6 \%$ at age 35 and remained stable thereafter. In the female subjects, the rates also increased with age, albeit at a slower rate, from age 20 to reach a plateau of $46.7 \%$ at age 55 and remained stable thereafter.

Conclusions There is a high prevalence rate of pterygium among the study subjects, with the rates increasing rapidly with age.

Eye (2006) 20, 908-912. doi:10.1038/sj.eye.6702046; published online 16 September 2005

Keywords: pterygium; epidemiology; prevalence; age-stratified prevalence; odds ratio
CSH Tan', TH Lim¹, WP Koh², GC Liew', ST Hoh², CC $\operatorname{Tan}^{4}$ and KG Au Eong 1,5,6,7

Introduction

Pterygium is a condition characterized by a fleshy growth on the conjunctiva. Although the growth itself is benign, it may cause visual impairment by encroaching on the visual axis or by inducing astigmatism. Its removal may be required for these reasons, and if the pterygium causes irritation or is deemed cosmetically unacceptable by the patient.

The prevalence rates of pterygium reported in different studies vary considerably $(0.35-31.1 \%)^{1-6}$ and may be affected by factors such as age, ${ }^{6,7}$ gender, ${ }^{6-8}$ ultraviolet (UV) radiation exposure, ${ }^{7-11}$ and time spent outdoors. ${ }^{1,3,12,13}$

Our study aimed to describe the epidemiology of pterygium among residents of a tropical island in Indonesia and to examine the roles of age and gender as determinants of bilaterality and severity of the disease.

\section{Methods}

A voluntary eye screening was conducted as part of a community health and welfare project for the inhabitants of Pulau Jaloh, a small tropical island in the Riau Archipelago of Indonesia. The principles of the Declaration of Helsinki were adhered to in the conduct of this study.

Examination of the anterior segment of the eye was performed by two qualified ophthalmologists using a portable hand-held slitlamp. The pupils were not dilated during the examination. The severity of pterygia, if present, was graded separately for both the nasal and temporal aspects of each eye. Pterygia were graded under standard lighting conditions based on the location of the pterygium head as follows:

Grade 0 - no pterygium

Grade 1 - head of pterygium at the limbus 
Grade 2- head of pterygium between the limbus and the undilated pupil margin

Grade 3-head of pterygium at the pupil margin

Grade 4 - head of pterygium within the pupil margin

Gender difference was tested using the $\chi^{2}$ test. The difference in age between subjects with and without disease was tested using unpaired Student's $t$-test and the $95 \%$ confidence intervals were calculated using the exact method. ${ }^{14}$ Odds ratio (relative risk) for gender was calculated using logistic regression model with adjustment for age. All statistical analyses were performed using SPSS for Windows (version 12).

\section{Results}

Of the estimated 550 inhabitants on the island, 477 were screened (response rate $=86.7 \%$ ), with a mean age of 22.8 years (range, $0-90$ years, $S D \pm 18.1$ ). There were 211 male $(44.2 \%)$ and 266 female $(55.8 \%)$ subjects. All the respondents had dark brown irides. Most of them had little formal education and began working outdoors in fishing-related occupations from their early teens.

A total of 81 subjects had pterygia, giving an overall prevalence rate of $17.0 \%$ (95\% CI, 13.9-20.6\%). The overall prevalence rate was significantly higher in male subjects $(48,22.7 \%, 95 \% \mathrm{CI}, 17.6-28.9 \%)$ compared to female subjects $(33,12.4 \%, 95 \%$ CI, 9.0-16.9\%) of all ages ( $\chi^{2}$ test, $P=0.003$ ). The age-stratified prevalence rates are also higher for male subjects compared to female subjects in all age ranges (Table 1). The prevalence rates in male subjects increased very rapidly with age from age 20 years to reach a plateau of $63.6 \%$ at age 35 years and remained stable thereafter. In female subjects, the rates also increased with age, albeit at a slower rate, from age
20 years to reach a plateau of $46.7 \%$ at age 55 years, after which it remained stable.

Subjects with pterygium were older (mean age 42.9 years) compared to those without (mean age 18.7 years) ( $t$-test, $P<0.001$ ).

Both eyes were equally affected, with 69 of 81 cases on the right $(85.2 \%)$ and 70 of 81 on the left $(86.4 \%)$. The majority of subjects had bilateral involvement (58 of 81 , $71.6 \%)$ while only 23 of $81(28.4 \%)$ were unilateral. Male subjects were more likely to have bilateral disease (38 of $48,79.2 \%$ ) than female subjects (20 of $33,60.6 \%$ ), although this difference was not statistically significant ( $\chi^{2}$ test, $P=0.083$ ). In both male and female subjects, bilateral disease may be present by the third decade of life (Table 1). In all age groups, the proportion of male subjects with bilateral disease was higher than female subjects.

The majority of pterygia occurred on the nasal side -69 of 81 subjects $(85.2 \%)$ had nasal pterygium only, none had temporal pterygium only $(0 \%)$, and 12 had both nasal and temporal pterygia $(14.8 \%)$.

The median grade of pterygia was the same (grade 1) for both male and female subjects, with $59.3 \%$ of the respondents having grade 1 pterygia, and $92.6 \%$ having either grade 1 or grade 2 pterygia (Figure 1).

Adjusted for age as a continuous variable, male subjects had an increased risk of disease compared to female subjects (odds ratio $=3.10,95 \% \mathrm{CI}=1.72-5.61$ )

\section{Discussion}

Our study showed the prevalence rate of pterygium in the Indonesian population on Pulau Jaloh to be higher than in many comparable studies. The prevalence rates of pterygium from various studies show considerable variation, ranging from less than 1 to $31.1 \%$ (Table 2). ${ }^{1-6}$

Table 1 Age-stratified prevalence of pterygium

\begin{tabular}{|c|c|c|c|c|c|c|c|c|c|c|c|c|}
\hline \multirow{3}{*}{$\begin{array}{l}\text { Age } \\
\text { (years) }\end{array}$} & \multicolumn{4}{|c|}{ All $(\mathrm{n}=81)$} & \multicolumn{4}{|c|}{ Male subjects $(\mathrm{n}=48)$} & \multicolumn{4}{|c|}{ Female subjects $(\mathrm{n}=33)$} \\
\hline & \multicolumn{2}{|c|}{ Unilateral } & \multicolumn{2}{|c|}{ Bilateral } & \multicolumn{2}{|c|}{ Unilateral } & \multicolumn{2}{|c|}{ Bilateral } & \multicolumn{2}{|c|}{ Unilateral } & \multicolumn{2}{|c|}{ Bilateral } \\
\hline & $\begin{array}{l}\text { Number } \\
\text { affected/ } \\
\text { number } \\
\text { screened }\end{array}$ & $\%$ & $\begin{array}{l}\text { Number } \\
\text { affected/ } \\
\text { number } \\
\text { screened }\end{array}$ & $\%$ & $\begin{array}{l}\text { Number } \\
\text { affected/ } \\
\text { number } \\
\text { screened }\end{array}$ & $\%$ & $\begin{array}{l}\text { Number } \\
\text { affected/ } \\
\text { number } \\
\text { screened }\end{array}$ & $\%$ & $\begin{array}{l}\text { Number } \\
\text { affected/ } \\
\text { number } \\
\text { screened }\end{array}$ & $\%$ & $\begin{array}{l}\text { Number } \\
\text { affected/ } \\
\text { number } \\
\text { screened }\end{array}$ & $\%$ \\
\hline $0-10$ & $0 / 157$ & 0.0 & $0 / 157$ & 0.0 & $0 / 92$ & 0.0 & $0 / 92$ & 0.0 & $0 / 65$ & 0.0 & $0 / 65$ & 0.0 \\
\hline $11-20$ & $2 / 104$ & 1.9 & 0/104 & 0.0 & $1 / 33$ & 3.0 & $0 / 33$ & 0.0 & $1 / 71$ & 1.4 & $0 / 71$ & 0.0 \\
\hline $21-30$ & $18 / 82$ & 22.0 & $13 / 82$ & 15.9 & $9 / 27$ & 33.3 & $7 / 27$ & 25.9 & $9 / 55$ & 16.4 & $6 / 55$ & 10.9 \\
\hline $31-40$ & $23 / 56$ & 41.1 & $17 / 56$ & 30.4 & $14 / 22$ & 63.6 & $12 / 22$ & 54.5 & $9 / 34$ & 26.5 & $5 / 34$ & 14.7 \\
\hline $41-50$ & $17 / 39$ & 43.6 & $13 / 39$ & 33.3 & $13 / 20$ & 65.0 & $11 / 20$ & 55.0 & $4 / 19$ & 21.1 & $2 / 19$ & 10.5 \\
\hline $51-60$ & $14 / 25$ & 56.0 & $10 / 25$ & 40.0 & $7 / 10$ & 70.0 & $5 / 10$ & 50.0 & $7 / 15$ & 46.7 & $5 / 15$ & 33.3 \\
\hline $\begin{array}{l}61 \text { and } \\
\text { above }\end{array}$ & $7 / 14$ & 50.0 & $5 / 14$ & 35.7 & $4 / 7$ & 57.1 & $3 / 7$ & 42.9 & $3 / 7$ & 42.9 & $2 / 7$ & 28.6 \\
\hline
\end{tabular}




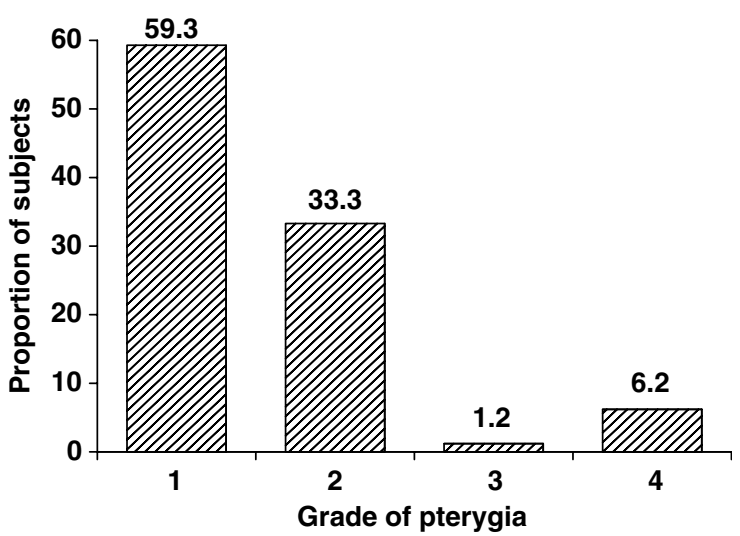

Figure 1 Proportion of subjects with various grades of pterygia.

However, the results reported by different groups may not be directly comparable since prevalence rates are influenced by factors such as the type of the population screened (general population compared to clinic-based), the age range of the respondents, variable exposure to environmental, occupational and other risk factors, as well as genetic differences between the populations. In addition, the grading systems used for pterygium vary between different studies, making it difficult to compare the severity of the disease.

The prevalence rate of $17.0 \%$ in our study is higher than most similar studies conducted in a general population..$^{1-4,6,7}$ This is especially significant considering that the screening involved all available inhabitants of the island, and the average age of our respondents was relatively young (22.8 years). Some other studies have reported a lower prevalence rate, despite excluding younger participants and screening only participants above a specific age. ${ }^{7}$

There are several factors that might explain the high prevalence of pterygium found in our study. Pulau Jaloh is a tropical island inhabited by a rural fishing community. The majority of the islanders, especially the male subjects, spend most of their working hours outdoors under the sun in activities related to fishing. Many of them start working at a relatively young age and do not wear sunglasses or other protective eyewear. The cumulative amount of time spent out in the sun from a young age might be a reason for the high overall prevalence of pterygium observed, as well as the fact that most develop bilateral disease before the age of 30 years.

$\mathrm{UV}$ radiation has been suggested as an aetiological factor in the pathogenesis of pterygium..$^{7-11}$ It is believed that UV light causes thickening and hyperplasia in subconjunctival connective tissue. Differences in exposure to UV radiation may account for the variation with geographical location and time spent outdoors, which is itself affected by the occupation of the subjects. Cameron described a 'pterygium belt' located between $37^{\circ}$ north and south of the equator, where pterygia are supposedly more common. The high prevalence among inhabitants of Pulau Jaloh, which is situated several degrees south of the equator, seems to support this observation. However, there are exceptions to this: inhabitants of the Solomon Islands have a low prevalence of pterygium $(0.3 \%)$ despite a similar location near the equator ( $6^{\circ}$ south of the equator). ${ }^{15}$ In contrast, Eskimos in Greenland have a relatively high prevalence $(9.6 \%)$ given its latitude of $61^{\circ}{ }^{16}$ Mackenzie $e t$ al ${ }^{9}$ demonstrated an age-adjusted relative risk of 36.3 for those who had lived at latitudes less than $30^{\circ}$ during the first 5 years of life. Since the majority of islanders of Pulau Jaloh have lived there since birth and migration is not common, Mackenzie and coworkers findings might be one factor that explains the high rate of pterygium among the islanders.

The amount of time spent working outdoors and exposed to sunlight is an important factor ${ }^{1,3,12,13}$ and affects the cumulative exposure to UV radiation. A case-control study in Brisbane showed a 4-11 times higher risk in people working outdoors compared to those who worked only indoors. The point estimates of risk varied with the age during which the subject spent time outdoors, being higher at a younger age than later in life. ${ }^{9}$ In a study in Indonesia, the prevalence of pterygium was significantly higher in those who had reported increased outdoor activity 10 years earlier. ${ }^{3}$

Our results support the evidence that pterygium increases in frequency with age, ${ }^{6,7}$ demonstrating both a significantly higher average age of subjects with pterygia (42.8 years) compared to those without (18.6 years) as well as a progressive increase in the prevalence rate age among both male and female subjects. Some earlier studies have also demonstrated an increase in prevalence rates when their patients were divided into different age groups. ${ }^{1}$ A recent study in Sumatra, Indonesia, showed an increase in prevalence from $2.9 \%$ in those aged 21-29 years, to $17.3 \%$ for those above 50 years. The overall prevalence rate for those above 40 years was $16.8 \%$. $^{3}$ A study in Central Sahara in Africa showed a prevalence rate of $18 \%$, which is comparable to ours. In that study, the authors demonstrated a statistically significant increase in age, from $1.1 \%$ in those aged 2-19 years to $13.0 \%$ in those aged $40-87$ years. $^{2}$

Gender has been suggested as another risk factor for the development of pterygia, although the results have been mixed, possibly confounded by other factors such as the populations being studied, lifestyle, and exposure to environmental risk factors. Some studies have demonstrated higher rates in male subjects compared to female subjects, ${ }^{6-8}$ whereas others have found no 
Table 2 Prevalence rates of pterygia reported in various studies

\begin{tabular}{|c|c|c|c|c|c|c|}
\hline \multirow[t]{2}{*}{ Authors } & \multirow[t]{2}{*}{ Study location } & \multirow{2}{*}{$\begin{array}{c}\text { Study } \\
\text { population (n) }\end{array}$} & \multirow[t]{2}{*}{ Age (years) } & \multicolumn{2}{|c|}{ Prevalence rate of pterygia (\%) } & \multirow{2}{*}{$\begin{array}{l}\text { Associated risk } \\
\text { factors }\end{array}$} \\
\hline & & & & (Unilateral) & (Bilateral) & \\
\hline $\begin{array}{l}\text { Bueno-Gimeno } \\
\text { et } a l^{2}\end{array}$ & Tindouf, Algeria & 1322 & $\begin{array}{l}\text { All ages } \\
2-19 \\
20-39 \\
40-87\end{array}$ & $\begin{array}{c}18.0 \\
1.1 \\
3.7 \\
13.0\end{array}$ & - & Increasing age. \\
\hline Gazzard et $a l^{3}$ & $\begin{array}{l}\text { Riau Province, } \\
\text { Sumatra, } \\
\text { Indonesia }\end{array}$ & 1210 & $\begin{array}{l}\text { All ages } \\
21-29 \\
50 \& \text { above }\end{array}$ & $\begin{array}{c}10.0 \text { (95\% CI, 8.2-11.7) } \\
\text { (age-adjusted } \\
\text { prevalence) } \\
2.9 \text { (95\% CI, 0.4-5.8) } \\
17.3(95 \% \text { CI, } \\
10.4-24.2)\end{array}$ & $\begin{array}{l}4.1(95 \% \mathrm{CI}, \\
2.9-5.3) \text { (Age } \\
\text { adjusted } \\
\text { prevalence) }\end{array}$ & $\begin{array}{l}\text { Increasing age. } \\
\text { Outdoor activity } \\
10 \text { years earlier. }\end{array}$ \\
\hline Luthra et $a l^{1}$ & $\begin{array}{l}\text { Barbados, West } \\
\text { Indies }\end{array}$ & 2781 & $40-84$ & $\begin{array}{c}23.4 \text { (black) } \\
23.7 \text { (black and } \\
\text { white) } \\
10.2 \text { (white) }\end{array}$ & - & $\begin{array}{l}\text { African ancestry. } \\
\text { Age. } \\
\text { Fewer years of } \\
\text { education. } \\
\text { Outdoor job } \\
\text { location. } \\
\text { Protective factors: } \\
\text { Darker skin } \\
\text { complexion. } \\
\text { Use of sunglasses } \\
\text { outdoors. } \\
\text { Use of } \\
\text { prescription } \\
\text { glasses. }\end{array}$ \\
\hline Wong et $a l^{6}$ & Singapore & 1232 & $40 \&$ above & $6.9(95 \%$ CI, 5.2-8.8) & $\begin{array}{c}2.9(95 \% \mathrm{CI}, \\
1.8-4.2)\end{array}$ & $\begin{array}{l}\text { Increasing age. } \\
\text { Male sex. } \\
\text { Occupations - } \\
\text { factory \& } \\
\text { production } \\
\text { workers, machine } \\
\text { operators, laborers } \\
\text { \& agriculture } \\
\text { workers. }\end{array}$ \\
\hline McCarty et $a l^{7}$ & $\begin{array}{l}\text { Victoria, } \\
\text { Australia }\end{array}$ & 5147 & $40-101$ & $\begin{array}{c}2.83 \text { (2.35-3.31) (Age } \\
\text { standardised } \\
\text { prevalence) }\end{array}$ & & $\begin{array}{l}\text { Age. } \\
\text { Male sex. } \\
\text { Rural residence. } \\
\text { Lifetime ocular } \\
\text { sun exposure. }\end{array}$ \\
\hline Rojas $e t a l^{5}$ & $\begin{array}{l}\text { Lima Peru } \\
\text { (Hospital } \\
\text { patients) }\end{array}$ & 367 & & 31.1 & 6.8 & Increasing age \\
\hline $\begin{array}{l}\text { Moran and } \\
\text { Hollows }\end{array}$ & Australia & $\begin{array}{c}64,314 \\
\text { Aborigines } \\
40799 \text { non- } \\
\text { Aborigines }\end{array}$ & $0-60+$ & $\begin{array}{c}3.4 \text { (Aborigines) } \\
1.1 \text { (non-Aborigines) }\end{array}$ & & $\begin{array}{l}\text { UV radiation } \\
\text { exposure }\end{array}$ \\
\hline
\end{tabular}

significant difference between the sexes. ${ }^{1,3,5}$ In our study, the prevalence rates among male subjects $(22.7 \%)$ were significantly higher compared to female subjects (12.4\%). This is in contrast to another study in an Indonesian population, in which the prevalence rates among female subjects $(17.6 \%)$ was actually slightly higher than in male subjects $(16.1 \%){ }^{3}$ The male subjects in ours study also exhibited a higher age-stratified prevalence rates in all age groups, developed pterygia at a younger age and also had a higher proportion of bilateral pterygia compared to female subjects.

In our study, the odds ratio for the development of pterygia increased with age for both sexes, although the increase was more rapid for male compared to female subjects. The age-adjusted ratio of 3.1 for male compared to female subjects is comparable to 4.2 found by Wong et al. ${ }^{6}$ 
Genetic and ethnic differences may account for varying prevalence rates, although this hypothesis could not be tested in our study since the population was relatively homogenous in terms of ethnicity. Pterygium was present in $23.4 \%$ of black subjects compared to $10.2 \%$ in white subjects in the Barbados Eye Study, representing a three-fold higher frequency of pterygium among those of African descent compared to white subjects. This is the highest rate reported for any group in a populationbased study. ${ }^{1}$ Moran and Hollows ${ }^{8}$ reported that the overall prevalence rate for Aborigines (3.4\%) was more than 3 times that of non-Aborigines (1.1\%). A higher prevalence rate in Aborigines was seen across all age groups.

Pterygium may affect one or both eyes and the proportion of bilateral disease also shows considerable variation, from $4.1^{3}$ to $67.3 \% .^{2}$ In our study, the majority of subjects had bilateral disease $(71.6 \%)$, with a higher proportion among male subjects $(79.2 \%)$ compared to female subjects $(60.6 \%)$, although this was not statistically significant. Interestingly, in both male and female subjects bilateral involvement may develop by the third decade of life. This may imply that genetic predisposition plays an important role and may also suggest the effect of exposure to various environmental factors, including outdoor environments and exposure to UV light, at a relatively young age.

In summary, our study showed the prevalence rate of pterygium in the Indonesian population on Pulau Jaloh to be higher than in many comparable studies. Male subjects had a significantly higher rate than female subjects. The majority had bilateral disease, which could develop by the third decade, suggesting the possible role of genetics or early exposure to risk factors such as UV radiation.

\section{Acknowledgements}

We have no proprietary or competing interest in the results of this paper and have not received any research funding during the course of the research. This paper was presented in part as a poster at the First SERI-ARVO (Singapore Eye Research Institute-Association for Research in Vision and Ophthalmology) Meeting on
Research in Vision and Ophthalmology, 6-9 February 2003, Singapore.

\section{References}

1 Luthra R, Nemesure BB, Wu SY, Xie SH, Leske MC. Frequency and risk factors for pterygium in the Barbados Eye Study. Arch Ophthalmol 2001; 119: 1827-1832.

2 Bueno-Gimeno I, Montes-Mico R, Espana-Gregori E, Pons AM. Epidemiologic study of pterygium in a Saharan population. Ann Ophthalmol 2002; 34(1): 43-46.

3 Gazzard G, Saw SM, Farook M, Koh D, Widjaja D, Chia SE et al. Pterygium in Indonesia: prevalence, severity and risk factors. Br J Ophthalmol 2002; 86: 1341-1346.

4 Saw SM, Tan D. Pterygium: prevalence, demography and risk factors. Ophthalmic Epidemiol 1999; 6: 219-228.

5 Rojas JR, Malaga H. Pterygium in Lima, Peru. Ann Ophthalmol 1986; 18: 147-149.

6 Wong TY, Foster PJ, Johnson GJ, Seah SK, Tan DT. The prevalence and risk factors for pterygium in an adult Chinese population in Singapore: the Tanjong Pagar survey. Am J Ophthalmol 2001; 131: 176-183.

7 McCarty CA, Fu CL, Taylor HR. Epidemiology of pterygium in Victoria, Australia. Br J Ophthalmo 2000; 84: 289-292.

8 Moran DJ, Hollows FC. Pterygium and ultraviolet radiation: a positive correlation. Br J Ophthalmol 1984; 68: 343-346.

9 Mackenzie FD, Hirst LW, Battistutta D, Green A. Risk analysis in the development of pterygia. Ophthalmology 1992; 99: 1056-1061.

10 Taylor HR, West S, Munoz B, Rosenthal FS, Bressler SB, Bressler NM. The long-term effects of visible light on the eye. Arch Ophthalmol 1992; 110: 99-104.

11 Taylor HR, West SK, Rosenthal FS, Munoz B, Newland HS, Emmett EA. Corneal changes associated with chronic UV irradiation. Arch Ophthalmol 1989; 107: 1481-1484.

12 Saw SM, Banerjee K, Tan D. Risk factors for the development of pterygium in Singapore: a hospital-based case-control study. Acta Ophthalmol Scand 2000; 78: 216-220.

13 Threlfall TJ, English DR. Sun exposure and pterygium of the eye: a dose-response curve. Am J Ophthalmol 1999; 128: 280-287.

14 Armitage P, Berry G. Statistical Methods in Medical Research, 3rd edn. Blackwell Science, Ltd: Cambridge, UK, 1994, pp 118-125.

15 Verlee DL. Ophthalmic survey in the Solomon Islands. Am J Ophthalmol 1968; 66: 304-319.

16 Norn MS. Prevalence of pinguecula in Greenland and in Copenhagen, and its relation to pterygium and spheroid degeneration. Acta Ophthalmol (Copenhagen) 1979; 57: 96-105. 